\title{
WHAT IS THE RESEARCH IMPACT OF (THE IDEAL OF) SCIENTIFIC TRUTH?
}

\author{
RENE BRAUER \\ Visiting Scholar, Karelian Institute \\ University of Eastern Finland, 80130 Joensuu, Finland \\ E-mail address: r.brauer@hull.ac.uk \\ ORCID: https://orcid.org/0000-0002-6762-6716 \\ MIREK DYMITROW \\ Lund University, Department of Human Geography \\ Sölvegatan 10, 22362 Lund, Sweden \\ \& \\ University of Gothenburg \\ Department of Economy and Society - Unit for Human Geography \\ 41125 Gothenburg, Sweden; \\ E-mail address: mirek.dymitrow@keg.lu.se \\ ORCID: https://orcid.org/0000-0002-6936-342X
}

\section{FILIPE WORSDELL}

Department of Strategy and International Business Surrey Business School

University of Surrey, GU2 7XH Guildford, Surrey, UK

E-mail address: f.worsdell@surrey.ac.uk

ORCID: https://orcid.org/0000-0002-0674-6677

JOHN WALSH

Independent Scholar

16 Fairview Terrace, Greenhill Rd, Garryowen, Limerick, V94X22RV Ireland

E-mail address: johnwalsh82@gmail.com

ORCID: https://orcid.org/0000-0001-7934-3871

\begin{abstract}
Aim. This paper elucidates how the emergent impact agenda is slowly but surely changing the normative framework of modern Western science.

Method. The paper investigates conceptually the implications of the impact agenda for the research process. We outline a chronology around the evaluation regime of research impact and identify the causal mechanisms that change the disciplinary structure of the research ecosystem. We draw upon a sociological model of scientific knowledge
\end{abstract}


production to contrast and discuss how impact facts mimic the process of scientific knowledge production but are geared towards a different end.

Results. Our findings indicate that an explicit emphasis on societal contribution not only propositions a different purpose of research, but also changes the logic of research along its entire construction. The impact logic mimics the creation of scientific facts; nevertheless, as it is geared towards a different end, it hermetically seals itself from criticism as any form of scrutiny would otherwise undermine its own legitimacy.

Conclusion. We conclude that only explicit acknowledgement of the adverse potential of the impact agenda can maintain science's benefit to society. We argue that an emphasis on the advancement of knowledge, as opposed to impact, can maintain innovation and preempt social tension. The contribution of this paper lies in identifying the societal influence of the scientific ideal of truth, and articulating the unintended consequences of the impact agenda as the emerging impact or starve paradigm.

Key words: research impact, unintended consequences, sociology of science, research ethics, evolutionary thinking

\section{INTRODUCTION}

"History never looks like history when you are living through it" (Gardner, 1968, p. 16)

$\mathrm{T}$ The introductory quote is from John W. Gardner, a central figure in the US research policy, whose ideas about research excellence were disseminated globally (Flink \& Peter, 2018, p. 441). The history-making events since the start of the millennium have been plentiful: the 9/11 attacks, the third Gulf War, the housing market bubble, \#Gamergate, Brexit, Donald Trump's presidency, ISIS attacks in Europe and COVID-19, just to mention a few events that have moulded our collective Zeitgeist in more ways than we can imagine. More subdued perhaps was the steady reshaping of the ethos of modern science, from the advancement of knowledge to that of the betterment of society, or research impact as it is now known (Holbrook, 2017). The latter gave rise to a research agenda, i.e., a push for an evaluation of the societal benefit of research (Crawford, 2020) and already in 2011, the question whether "the impact agenda will create a Franksteinian monster[?]" was underway (Martin, 2011, p. 247). By exploring its implications for the very value of the scientific truth ideal, this paper speaks to everybody affected by this concept: academics who facilitate it, administrators and policy makers who manage it, and the public as its purported recipient.

The rhetorical appeal behind the impact agenda lies in its rationale to justify the public funding of research and higher education, and hence is "not going to go away" any time soon (Finch, 2016, p. 6). The danger is that this drive for utility and public accountability not only increases workload, challenges trust and motivation towards and between academics (Chubb \& Reed 2018), but also shackles academic freedom (Smith et al. 2011) and accentuates the tensions that exist between science and politics (Weingart, 1999). Regardless, industry, governments and funding bodies are urging research institutions to maximise 
impact (e.g. Economic and Social Research Council [ESRC] website, 2020), which the latter, in turn, echo to claim they have had enormous impact on the world over the centuries (e.g. University of Oxford website, 2021). Thereby, the impact agenda influences academia's internal moral economy, and as of yet it is uncertain how this will shape the wider moral economy of society in general. A moral economy is one that depends upon voluntary reciprocal game-playing of the participants, as opposed to financial markets that are thought to be independent from such considerations. We view this "concept capable of representing the workings of modern civil society" (Götz, 2015, p. 148) and use it here to explore the relationship between academia and society. Hence, the epistemological difference between impact and scientific claims caused by a shift in the research assessment regime represent the knowledge gap of this conceptual paper. This ambition resounds in our titular research question.

To operationalise our aim of exploring how the research impact assessment regime changes the normative structure of modern research, we have three research objectives. Firstly, to provide a brief chronology of the history of the research impact evaluation and establish the causality of how this concept reshapes scientific knowledge production. Secondly, to highlight the functional importance of the scientific truth ideal in how scientific facts become true in the research ecosystem. Thirdly, to outline how the impact agenda is creating its own epistemological regime of justification under the guise of scientific knowledge production. In our discussion, we utilise methodological considerations to highlight the difference between how an impact vs. scientific regime value the advancement of knowledge on an individual level, before discussing the implication on a societal wide level and presenting our contribution. A conclusion summarises the two main challenges.

\section{RESEARCH OBJECTIVE ONE: A CHRONOLOGY OF IMPACT DISCIPLINING}

Before deep diving into the chronology of research impact, we want to make clear that we are not averse to research beneficially influencing society. We are concerned with the wider effects of evaluating research based on its impact. In this section, we focus on how this evaluation regime became part of research assessment ("A short history of research impact assessment and brief literature review"), and the causality of how its associated disciplinary regime changes scientific knowledge production ("Change the disciplinary rules, change the game").

\section{A Short History of Research Impact Assessment and Brief Literature Review}

Starting in 2001, Australia was amongst the first countries who officially suggested 'research impact' as a part of their national Research Quality Framework. Nevertheless, they abandoned the idea on the eve of its implementation due to a change in government, i.e. the snap elections of 2007. The newly 
elected Labour government claimed the criterion was " poorly designed, administratively expensive and relie[d] on an impact measure that is unverifiable and ill-defined" (Williams \& Grant, 2018, p. 97), only to reintroduce it with the Excellence in Research for Australia Framework in 2012. In the UK, these early Australian discussions were a source of inspiration. What later became known as the Warry Report (Warry, 2006) was amongst the first arguing that research's influence upon society ought to represent an integral part of British academic evaluation. Subsequently, UK government departments, such as the treasury and funding councils then endorsed these political arguments (e.g., Her Majesty's Treasury, 2006; Higher Education Funding Council for England [HEFCE], 2007). All this cumulated into the addition of 'research impact' as an official assessment requirement of the rebranded 2014 Research Excellence Framework (REF) (HEFCE, 2009), which came to replace the previous national Research Assessment Exercise (RAE).

With its implementation into the REF, the impact assessment got its first application, producing 6975 so-called impact case studies, 75\% of which were rated as internationally excellent or world-leading (HEFCE, 2015). An impact case study is a four-page document that has become the standard form of assessing research impact. Thereby, similarly to how the idea of systematic research evaluation of the RAE spread research metrics around the world (Wouters et al., 2015), impact has now also gained global traction. As such, the introduction of impact assessment spawned a lot of research. The next paragraph serves as a brief literature review to situate our knowledge gap.

Most of research on impact focuses on the pragmatics of working with it in order to further the impact agenda. Such research ponders everything from: how to utilise impact for academic career advancement (e.g., Reed, 2018), improve co-production of knowledge (e.g., McCabe et al., 2021), streamline evaluation of research proposals (e.g., Allbutt \& Irvine 2019), better promote their own discipline (e.g., Jones et al., 2021) or shape research agendas to be more impactful (e.g., Hicks \& Holbrook, 2020), to only mention a few. Even when critical of the impact agenda, it is mostly parochial: in terms of the ability to accurately assess impact (e.g., Lauronen, 2020), questioning of what this does in terms of research ethics (e.g., Macfarlane, 2019), how impact claims differ epistemologically between science, technology, engineering and maths (STEM) subjects, and social sciences and humanities research (e.g., Bonaccorsi et al., 2021) or how the writing of case studies changes the relationship of researchers' to their research (e.g., Wróblewska, 2021). Only a few researchers make the leap and question the entire process of knowledge production (e.g., Shields \& Watermeyer, 2020). Even if they do, it is primary along the lines of academic identity (e.g., Watermeyer, 2019) or epistemic corruption (e.g., Kidd et al. 2021), were any systematic changes to the entirety of scientific knowledge production at research institutions represent the background discussion. 


\section{Change the disciplinary rules, change the game}

Notions that publicly funded research is beneficial to the economy, government, industry, and the like have existed for a long time (e.g., the idea of a triple helix by Etzkowitz and Leydesdorff, 1997). Usually, any performance-based evaluation system that implements such notions also stresses the need for greater transparency as a part of its rationale (Hicks, 2012). Whilst such sentiments may appeal to the values of academic accountability, in practice they tend to create tensions and complicate the research process (see Strathern, 2000). Traditionally, the internal moral economy of research communities fulfilled this quality assurance mechanism (Kohler, 1994). The proliferation of the impact agenda stems not only from research impact now being used as an evaluation requirement, but also from it being consequently linked directly or indirectly to funding opportunities. Thereby, the moral economy researchers must navigate (Tribe \& Liburd, 2016) sees its incentives and disincentives changed. Whilst the change may have been gradual, subtle, and even partially welcomed, it has created paradoxes between the autonomy, utility and practical management of research, by laying bare a "potential oppositionality of value dimensions" (Shields \& Watermeyer, 2020, p. 12). Put crudely, any claims of factualness (implying an ideal of truth) reveal their bias when linked to the benefit of the agenda they further, be it political, economic, industrial, or personal.

With a slew of performance indicators (grant income targets, $\mathrm{PhD}$ completion rates, citation counts; see Ten Holter, 2020), the impact assessment transpires as yet another box to tick, although it changes the purpose of research from the advancement of knowledge to societal benefit. When the purpose of research aligns with that of external agendas, researchers will receive praise, funding, and prizes. Research impact then becomes "a new form of scholarly distinction [that is] far more a matter of taste" (Watemeyer \& Chubb, 2019, p. 1564) when compared to that of rigorous research. However, what happens when research findings contradict, criticise, or challenge such agendas? The survivor bias of successful accounts makes them only partially useful; still, the normalisation process marches on. Doctoral programmes offer impact training (e.g., ESRC website, 2021), so-called pathways to impact are now an ostensible part of grant proposals (e.g., Livingstone-Banks, 2020), participation in writing impact case studies represents a requirement for the promotion to professorship in the UK, and the impact agenda is a part of the evaluation process of the research environment (HEFCE, 2019). We will return to how this push for societal influence reshapes the moral economy of the research ecosystem in section four. For now, let us look at how the emphasis on the advancement of knowledge facilitated ideas about scientific truth. 


\section{RESEARCH OBJECTIVE TWO: SCIENTIFIC TRUTH AS A GUIDING METAPHOR FOR RESEARCH}

Our second objective was to highlight the functional importance of certain values in the creation of scientific facts. To fully understand the impact of the notion of scientific truth, we need to first define and comprehend its creation process, i.e., how research functions. We will argue that the idea of scientific truth represents a baseline to retain the functionality of the research ecosystem ("Scientific truth as a baseline for a functioning research ecosystem"). We will also outline that the value of the advancement of knowledge has sociological importance in the knowledge production process ("A sociological model of the structured advancement of knowledge"), where functionality is understood as a productive non-violent means of conflict resolution ("The ideal of 'scientific truth' as a means of non-violent conflict resolution").

\section{Scientific truth as a baseline for a functioning research ecosystem}

Our view of scientific knowledge production entertains a sociological understanding of the research process. We can characterise it as a form of learned connoisseurship (Shapin, 2010) that encultures aspiring researchers into the art of expertise (Collins H. M. \& Evans, 2008). Important to note, is that such enculturing happens as a by-product of the inter-generational research effort, meaning both students and teachers participate in the research process. Such intergenerational conviviality then transmits the vital normative structures research depends on to the next generation (Merton, 1973). The aspiring researchers then internalise the underpinning values of the scientific method as the latter enables the communication of their new ideas with other scholars in their discipline. We believe it matters little if we relate to this internalisation process as a: thought collective (Fleck, 1936/1979), a republic (Polanyi, 1962/ 2000), an episteme (Foucault, 1966/2001), a rhizome (Deleuze \& Guattari, 1980), a habitus (Bourdieu, 1984/1988), an actor-network (Latour, 2005), an Erziehungssystem (German for: education system, Luhmann, 1978/2002), a university (Barnett, 1990), a tribe (Tribe, 2010), or - as we label it here - a research ecosystem. They all describe a self-replicating cultural system with ever-evolving standards of what is considered scientifically true. What matters is the vitality of the research culture, the validity of its claims, and the recognition of their limitations by the collective of its practitioners, i.e. the researchers (Gieryn, 1999). This in itself is contingent upon the values that practitioners are allowed to manifest in the resulting moral economy that creates a recursive cultural propagation of advancing knowledge over the centuries (Sztompka, 2007). Hence, the value of the advancement of knowledge creates a discursive regime that makes scientific knowledge trustworthy. Put differently, agreement is found through non-coercive means and the resulting claims are then considered as true. Some go as far as labelling this acquisition of scientific reasoning as a self-contained ideology in its own right (Habermas, 1968). 
If we want to get technical about what defines when scientific facts become true, i.e. what distinguishes scientific reason from political ideology or religion, we have to understand the research process as the result of negotiations between experts and non-experts within specific fields of knowledge that occur over different discursive spaces, such as peer review, competitive funding, university appraisals, funding applications, government standards, the classroom, supervision, outreach, administration, archiving etc. In their totality, these structural elements constitute the infrastructure necessary to make the research process work. Therefore, we label it a research ecosystem in this paper. Many different motifs, needs, desires, emotions, hopes and disappointments are presented as a unified objective fact, devoid of human passions that were the motor of their creation. In fact, by defining the research ecosystem in such a way, we are also, by extension, defining the very ideal of scientific truth and how it advances knowledge. It happens as the collective result of many different negotiations between actors who unify their different agendas under one collective purpose within the research ecosystem (Latour, 1988), that of the advancement of knowledge. In other words, this objective creates the facts. Thereby, a cultural process inseparably binds the function and purpose of the research ecosystem to the very action and values of the researchers and their institutions.

\section{A sociological model of the structured advancement of knowledge}

Any scientific sub-discipline functions along similar structural lines, be it physics (Collins H. M., 2010), climate science (Edwards, 2010), economics (MacKenzie, 2009), geology (Porter, 1977), health sciences (Mol, 2002), human geography (Dymitrow \& Brauer, 2018) or the humanities (Lamont, 2009). A problem that emerges is the difficulty to compare different arenas of expertise against each other. Seen in terms of functionality of the research ecosystem, we argue this becomes a problem, that is, when the purpose is anything other than the advancement of scientific knowledge. But why does it happen?

Fig. 1 describes the scientific method that turns input (data) into output (scientific facts) within the scope of the research ecosystem. All scientific knowledge production undergoes the following: a critical deconstruction (1) of the available literature, in which interpersonal communication is aided as it maps out the territory (how, why, and what) of the phenomena studied, both presently and in the past, as well as providing concepts, references and examples of how to authoritatively describe it. Such authority is only maintained if researchers also communicate in a fashion that is intelligible to others, hence authority is meritocratic bound to the ability to articulate. It is restricting, as the research norms posit that pre-existing knowledge ought to be considered (Latour, 2013).

Concerning the analytical construction (2), this is beneficial for communication, as it allows the individual accessing the information to deem if that evidence is reliable or not, as the premises that led the author(s) to their claim(s) have to be outlined. Such methodological heuristics are enabling, as the researcher does not have to invent analytical methods from scratch and hope that 


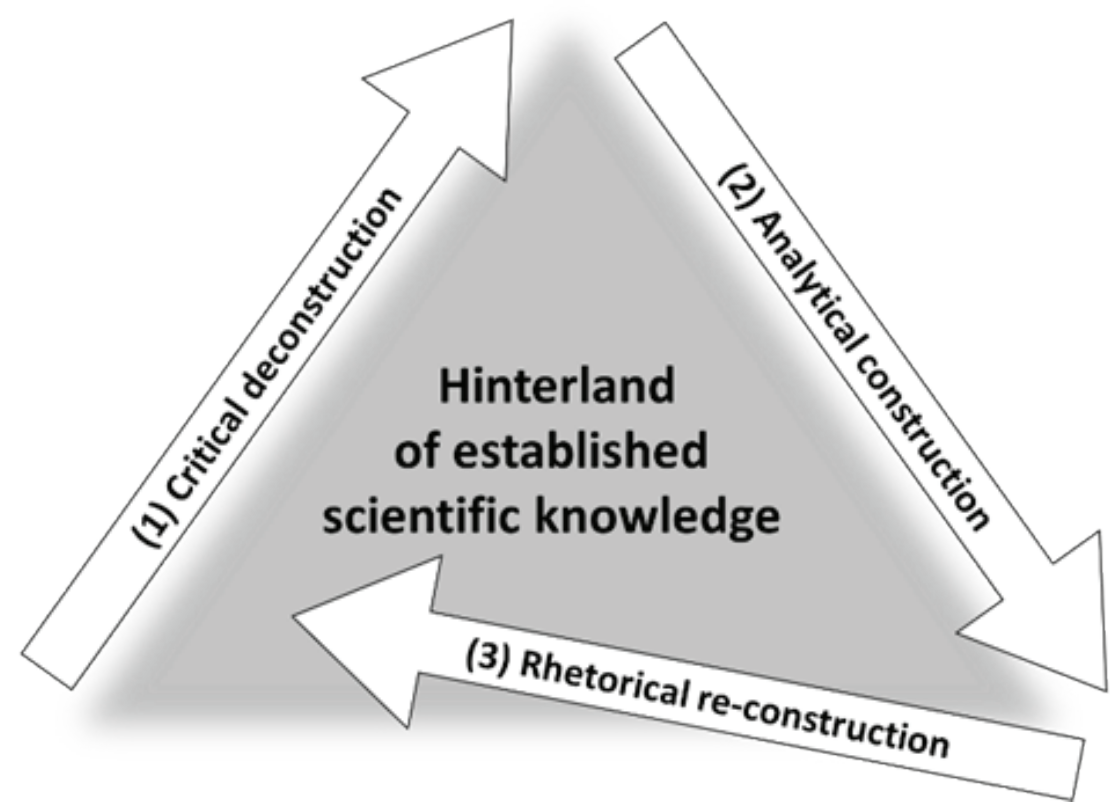

Fig. 1. Illustration of the research process that produces scientific facts, which is an extension of an earlier sociological model of scientific knowledge production (see: Brauer \& Dymitrow, 2017; Brauer, 2018)

Source: own research

they are acceptable to the wider community. However, at the same time it also means that 'old' methods get recycled constantly, leaving a relatively small pool of acceptable methods and articulation conventions that have to be used (Law \& Urry, 2004).

Finally, within the rhetorical re-construction (3), the claim is reassembled in its totality, becoming a scientific fact once published in an academic journal. The reason why this is beneficial for communication is that no matter what approach is used, each has its own constraints and challenges that influence the articulation (Feyerabend, 1975). This means that a multitude of possible theoretical contradictions in combination with many methodological problems potentially multiply so much that communication breaks down entirely. In order to mitigate this problem and facilitate functional communication, the rhetorical re-construction adds further constraints on how the information needs to be structured and presented (Pinker, 2015). The standard that many articles start with an abstract, then introduction, background, theory, methodology, results, discussion and conclusion is a norm for a reason.

Disciplinary norms enable/restrict each step of this process, and such norms have Christian/Western cultural roots much deeper than the Enlightenment, with the explicit purpose of advancing (scientific) knowledge, i.e., logos which 
is the root of our idea of logic (Hannam, 2009). As an aside, within the Christian theology, Jesus Christ is regarded as 'logos incarnate' (i.e. the embodiment of the word), making him a role model for the entirety of Christendom. Robert K. Merton, the famous sociologist of science, is the person who coined the very idea of role model (Kaufmann, 2003). Merton often stressed the importance of the role model of the teacher in the transmission of research skills and values to the student. In large, through an unimaginable extensive trial and error process, we today have arrived at a cultural system that can communicate, albeit the incorporation of new knowledge only occurs with great difficulty. Human communication is not arbitrary; it must follow certain principles of narrative, style, use of evidence or consistency of nomenclature to become mutually intelligible (Pinker \& Prince, 2002).

The ideal of scientific truth as a means of non-violent conflict resolution

The primary reasons of why we have simplified this complex process into these three steps is so we can apply it to the natural sciences, medicine, social science, and the humanities, which are all expected to showcase impact under our contemporary assessment regimes. In English, the word science carries the connotation of only referring to the natural sciences, this is a difference that does not exist within the German or Swedish language for example, where science translates to knowledge craft (German: Wissenschaft, Swedish: vetenskap). It is in such an artisanship sense that we here see the research process, where specific disciplinary rules get to structure human-to-human interaction if research is to be seen as a meaningful form of communication (Luhmann, 1992). To highlight its recursive and iterative nature, we present the process in a loop (see Fig. 1), as past research influences this inter-generational process of how new knowledge becomes part of the established ecosystem (Law, 2004). The critical deconstruction and analytical construction can be cast as unscientific and nonsensical by established peers, as they occur within the mind of the author(s) of the rhetorical re-construction. The differentiation between nonsense (i.e., meaningless) and no sense (as in: this does not make sense to me) is non-trivial when the subject matter pertains to new knowledge (see Wittgenstein, 1953/1986). By the very fact that it is new knowledge, it is none sense until properly articulated. Thereby, any new scientific fact represents a contradiction in terms in the sense that individually, each word trivially leads to the next, yet the claim in its totality is controversial/new. Such tensions are intrinsic to the research process; otherwise, the claim represents either already established knowledge or nonsense. The proper articulation is what sets the claim apart, i.e., makes it scientific.

If new knowledge is not presented within the accepted forms of the rhetorical re-construction, the new knowledge claim can be easily dismissed (Collins \& Pinch, 1979). If contentious claims do manage to become part of the established canon, post hoc such instances are then described as hoaxes in order to retain the integrity of the research ecosystem e.g., the Bogdanov affair (Woit, 2006). Descriptively the above outline is satisfactory in understanding when commu- 
nication breaks down, however the mystery lies in how do human beings with different subjective views of reality can communicate in an objective mutually intelligible fashion in the first place? As we stated within our titular research question, scientific truth is an ideal. Nevertheless, pragmatically it represents an encultured structuring metaphor (see Lakoff \& Johnson, 2008) for societal wide communication (e.g., being inferred when speaking of alternative facts/ fake news). When all scientific transformations are masterfully integrated, the information presented is understood as a fact, making it an indistinguishable part of the established scientific canon. Along the entire social construction of a scientific fact (from epistemology to correcting the last tiny mistake before publishing), rules and norms both enable and constrain research conduct, i.e., they discipline (Foucault, 1972). Furthermore, maintenance of the communication dimension is indifferent to the sentiments or specific goals of the individuals. The cultural norms that allow the researchers/teachers to enculture their students eventually becoming teachers themselves, have all grown in order to further the advancement of knowledge (Campbell, 1974). We argue the highest purpose of the research ecosystem must remain the advancement of scientific knowledge (Pinker, 2018) in order not to jeopardise the positive functionality that the ideal of scientific truth offers in terms of non-violent conflict resolution in communicating on contentious issues. Otherwise, communication will rupture, and violence - in whatever form - represents the only alternative of conflict resolution.

\section{RESEARCH OBJECTIVE THREE: THE NORMALISATION OF THE IMPACT AGENDA}

Our third objective was to outline different dimensions of the push for impact and to discuss how this reshapes the normative structure of the research ecosystem. We have divided this section into five thematic parts. Within these, we successively raise the level of abstraction from the trivial to the profound. The first contemplates career progression of early career researchers and reflects of what this means in terms of the critical deconstruction ("Career progression of early career researchers" ${ }^{\prime \prime}$. The next section investigates workload requirements and contrasts this to the analytical construction ("Increased workload and the mental health of the successful"). The third section reviews impact as a new form of scholarly distinction and discusses this in light of the rhetorical re-construction ("New modality of scholarly distinction"). The next two sections then discuss how the impact agenda is creating its own separate regime of truth generation ("Who decides what good impact is?") and what consequences this has on the very idea of research ("The problem of incomplete measurement").

\section{Career progression of early career researchers}

In terms of the critical deconstruction, the impact agenda has direct and diffused consequences. One of the direct consequences is that early career rese- 
archers have no basis to question it by, other than the (limited) knowledge of their educators who are currently complying with it. From the view of the early career researcher, impact appears on the curriculum after courses in research methodology, research ethics and data storage requirements for example. As such, it is unsurprising that the early career researchers' simply see it as just another part of the research process when taught the mechanics of generating impact (e.g., marketing, networking, generating resources etc.). That there is a shift towards market forces instead of the advancement of knowledge in the research collaborations facilitated by the impact agenda (Stahl et al., 2019) may come as a surprise to early-career researchers if they are not sensitized to it. Potential long-term consequences are such that once the early-career researchers become the teachers only the 'ignorant', 'uncultured', 'obstinate', 'uncooperative', 'idealists' will dare to criticise research that is striving for a (supposed) benefit for society. That such 'benefit' was construed alongside a neoliberal impact view and further exacerbated problems already present around the (failing) enculturation of the next generation (Lambert, 2019) will then be deemed as irrelevant. After all, the individuals had impact and their career, status and prestige are the proof of their own 'scientific' expertise!

\section{Increased workload and the mental health of the successful}

In relation to the analytical construction, the disciplining of researchers through writing impact case studies, pathways to impact and impact strategies are no mere forms to be routinely completed. A good way to understand them is as boundary objects (Star \& Griesemer, 1989), where many different agendas overlap and the researcher has to integrate their own research ambitions, strategic aims, funding requirements, technical aspects of the writing process, stakeholder engagement, availability of evidence, departmental politics, contracting, overheads, work allocation etc., all into a coherent narrative. Furthermore, the struggles that come with 'just' articulating a commodified version of research impact in order to generate research funds from the government is by no means a straightforward task (cf. Brauer \& Dymitrow, 2021). Nevertheless, all of these activities - in relation to compiling the evidence, articulating the narrative and doing this ethically and rigorously - are now just another workload responsibility of researchers. Thereby, the normalisation process is in full swing, shifting academic knowledge production from the advancement of knowledge to supposed societal benefit. Such managerialism finds support by the ambitions of the researchers themselves, in this race to the bottom (Ingold, 2020). If any problems arise in the process, the disciplinary machinery holds the academic responsible, as it is unable to infer that its own conduct maybe counter-productive.

\section{New modality of scholarly distinction}

Research in the moment of discovery is not 'rational', as it represents a process of exploration. Only post hoc, once all the different rationales, outcomes, misunderstandings, etc. are mapped and explored does it become rational (Angell \& Demetis, 2010). Thereby, the final account is a rhetorical 
re-construction of the process of discovery that is not representative of how the actual research process unfolded. Furthermore, if the moral economy of the research ecosystem is too rule-bound, too restrictive, too boxed, and has not the advancement of knowledge as it highest purpose, what its outcome will be is most likely a regression to the mean. The conflict between institutional ruthless evolutionary survival needs and what is beneficial according to the encultured ethos of the advancement of knowledge seems to be exacerbated by the disciplinary performance indicators like that of impact (cf. Dymitrow \& Brauer, 2017). Thereby, the gamification of research that is directly related to the crisis of replicability (Biagioli et al., 2018) is further accelerating a post-truth world. As now the reward structure promises research funds and career advancement to whom can boost most competently, according to the current tastes of the research impact evaluators.

\section{Who decides what good impact is?}

Our lamentation with the impact agenda is not that research is not supposed to benefit society. Rather, that more subdued and tacit impacts of the research ecosystem on society, such as teaching the public, enculturing the next generation and/or driving knowledge forward, may not represent a countable research impact leading to their diminishing appreciation. Thereby, rather than casting our point of contention as a mere ideological, ethical or epistemological difference, we construe it as an emergent property of neopragmatism, afforded by our contemporary technological and social circumstances (see Irwin, 2007). 'Pragmatically', if research results do not increase the individual's status, cannot be commodified into patents, earn money or make a measurable change in the next assessment period, such research can be construed as 'useless' (Brauer, 2020). Evaluation systems, such as the UK REF are a disciplinary mechanism that creates such discursive forces (Sayer, 2014). Our conceptual paper wants to draw attention to the consequences of such conduct and what will happen when the facts contradict the agendas research is meant to benefit.

\section{The problem of incomplete measurement}

Not only are current assessment models too short-sighted to appreciate the deep impact and knock-on effects of shared knowledge production (Woolcott et al., 2020), as stated previously, the very act of measuring impact in the first place creates a different value hierarchy. By measuring research impact and awarding prestige, funding and career advancement based on it, it is changing the moral economy of the research ecosystem by making its purpose of societal benefit explicit. Furthermore, as pecuniary rewards are associated with it, now when the individuals' personal agendas clash (e.g., advancement of knowledge, political motivations, career advancement, enculturing students etc.), whomever wins, will propagate their [personal] impact agenda as 'best practice', bolstering the institution's bottom line. With such an eventuality, we can no longer speak of research per se, as only the 
discovery of new knowledge classifies as such. Instead, what we then get is activism masquerading as research in the pursuit of some supposed 'greater good'. Furthermore, the moral self-licensing we all engage within (see Messner \& Brügger, 2015) then inadvertently justifies antagonising any means that potentially might contradict the experiment/basic/applied/research/ assessment/agenda/career goal, as the distinction between these categories has lost their meaning.

\section{DISCUSSION: A NEW PARADIGM FOR ACADEMIA?}

In our discussion we are reflecting upon the consequences of this changing evaluation regime both on an individual level ("Consequences for advancing knowledge on an individual level") and on a collective one ("Consequences for advancing knowledge on a general level"), in terms of what type of future research culture this may breed.

\section{Consequences for advancing knowledge on an individual level}

We have included autoethnographical reflections, so we can highlight the epistemological dimension of how the ideal of scientific truth allows for challenging normalised assumptions constructively. For a more elaborate methodological outline of the underpinning research programme, please consult the associated publications (in specific see: Brauer, 2018, 2019; Brauer et al., 2020; Brauer, Arsovski, \& Dymitrow, 2021; Brauer, Dymitrow, Tribe, 2021; Dymitrow \& Ingelhag, 2020). Jürgen Habermas (1968) differentiates three different epistemological regimes: (1) the technological regime of the sciences, (2) the historical-hermeneutical regime of the humanities, and (3) an emancipatory regime; as the basis of reflection and critique of the social sciences. An impact assessment regime does away with this distinction. Methodologically, we hope that by self-reflexively reporting how the process of creation of a scientific fact is established, our argument that the impact agenda is undermining these regimes gathers more traction. If we use the nomenclature introduced in section three to track our own argument construction, we can plot the following trajectory in Table 1. 
Table 1

Necessary steps in questioning normalisation for the first author

\begin{tabular}{|c|c|c|c|}
\hline Timeline & Critical deconstruction & Analytical construction & $\begin{array}{l}\text { Rhetorical } \\
\text { re-construction }\end{array}$ \\
\hline Q4-2014 & $\begin{array}{l}\text { choice of research } \\
\text { topic }\end{array}$ & $\begin{array}{l}\text { familiarisation with } \\
\text { REF } 2014 \text { process }\end{array}$ & $\begin{array}{l}\text { articulation of research } \\
\text { question }\end{array}$ \\
\hline Q1-2015 & $\begin{array}{l}\text { immersion in the } \\
\text { sociology of science }\end{array}$ & $\begin{array}{l}\text { first articulation of } \\
\text { methodology }\end{array}$ & $\begin{array}{l}\text { feedback from Prof. } \\
\text { John Tribe on the } \\
\text { method }\end{array}$ \\
\hline Q2-2015 & $\begin{array}{l}\text { exploration of the idea } \\
\text { of unintended harm }\end{array}$ & $\begin{array}{l}\text { pilot interview with } \\
\text { Prof. Leo Jago }\end{array}$ & $\begin{array}{l}\text { amending research } \\
\text { design due to the } \\
\text { feedback }\end{array}$ \\
\hline Q3-2015 & $\begin{array}{l}\text { immersion within } \\
\text { methodological } \\
\text { literature }\end{array}$ & $\begin{array}{l}\text { informal interviews } \\
\text { with scholars }\end{array}$ & $\begin{array}{l}\text { first articulation of } \\
\text { parts of this article }\end{array}$ \\
\hline Q4-2015 & $\begin{array}{l}\text { immersion within } \\
\text { criticism of REF } 2014\end{array}$ & $\begin{array}{l}\text { participant } \\
\text { observations on } \mathrm{PhD} \\
\text { impact training }\end{array}$ & $\begin{array}{l}\text { articulation of ideas for } \\
\text { scientific conferences }\end{array}$ \\
\hline Q1-2016 & $\begin{array}{l}\text { immersion within } \\
\text { evolutionary } \\
\text { psychology }\end{array}$ & $\begin{array}{l}\text { participant } \\
\text { observations on impact } \\
\text { conferences }\end{array}$ & $\begin{array}{l}\text { participant } \\
\text { observations on } \\
\text { academic writing } \\
\text { training }\end{array}$ \\
\hline Q2-2016 & $\begin{array}{l}\text { immersion within } \\
\text { philosophy of science }\end{array}$ & $\begin{array}{l}\text { in depth analysis of } \\
\text { REF } 2014 \text { guidelines }\end{array}$ & $\begin{array}{l}\text { development of } \\
\text { ideas in regard to } \\
\text { disciplining }\end{array}$ \\
\hline Q3-2016 & $\begin{array}{l}\text { immersion within } \\
\text { linguistics }\end{array}$ & $\begin{array}{l}\text { application of } \\
\text { evolutionary } \\
\text { psychology routines }\end{array}$ & $\begin{array}{l}\text { peer review of the here } \\
\text { expressed ideas online }\end{array}$ \\
\hline Q4-2016 & $\begin{array}{l}\text { immersion within } \\
\text { cognitive psychology }\end{array}$ & $\begin{array}{l}\text { field testing of ideas on } \\
\text { disciplining }\end{array}$ & $\begin{array}{l}\text { reflections articulated } \\
\text { in online forums }\end{array}$ \\
\hline Q1-2017 & $\begin{array}{l}\text { immersion within } \\
\text { history of ideas }\end{array}$ & $\begin{array}{l}\text { first round of } \\
\text { interviews }(n=13)\end{array}$ & $\begin{array}{l}\text { transcription of } \\
\text { interviews }\end{array}$ \\
\hline Q2-2017 & $\begin{array}{l}\text { immersion within } \\
\text { sociology of expertise }\end{array}$ & analysis of interviews & $\begin{array}{l}\text { write up first round of } \\
\text { interviews into a thesis }\end{array}$ \\
\hline Q3-2017 & $\begin{array}{l}\text { immersion within } \\
\text { sociology of } \\
\text { innovation }\end{array}$ & $\begin{array}{l}\text { informal peer review } \\
\text { in online forums }\end{array}$ & $\begin{array}{l}\text { write up and } \\
\text { refinement according } \\
\text { to feedback }\end{array}$ \\
\hline Q4-2017 & $\begin{array}{l}\text { dialectic with Prof } \\
\text { Keith Hollinshead }\end{array}$ & $\begin{array}{l}\text { field testing ideas on } \\
\text { discipline in online }\end{array}$ & $1^{\text {st }}$ draft of this paper \\
\hline Q1-2018 & $\begin{array}{l}\text { discovery of ethical } \\
\text { problems with data set }\end{array}$ & $\begin{array}{l}\text { sociology of university } \\
\text { employment process }\end{array}$ & $\begin{array}{l}\text { start of being an } \\
\text { impact officer for REF } \\
2021\end{array}$ \\
\hline Q2-2018 & $\begin{array}{l}\text { discussions with } \\
\text { scholars at place of } \\
\text { work }\end{array}$ & $\begin{array}{l}\text { second round of } \\
\text { interviews }(n=26)\end{array}$ & $\begin{array}{l}\text { transcription of } \\
\text { interviews }\end{array}$ \\
\hline Q3-2018 & $\begin{array}{l}\text { immersion within } \\
\text { theology }\end{array}$ & $\begin{array}{l}\text { analysis of research } \\
\text { interviews }\end{array}$ & $2^{\text {nd }}$ draft of this paper \\
\hline
\end{tabular}




\begin{tabular}{|c|c|c|c|}
\hline Timeline & Critical deconstruction & Analytical construction & $\begin{array}{l}\text { Rhetorical } \\
\text { re-construction }\end{array}$ \\
\hline Q4-2018 & $\begin{array}{l}\text { correspondence with } \\
\text { Prof. Glenn Burgess }\end{array}$ & $\begin{array}{l}\text { informal interviews to } \\
\text { corroborate ideas }\end{array}$ & $\begin{array}{l}\text { incorporation of } 2^{\text {nd }} \\
\text { round of interviews } \\
\text { data }\end{array}$ \\
\hline Q1-2019 & $\begin{array}{l}\text { correspondence with } \\
\text { Prof. Ronald Barnett }\end{array}$ & $\begin{array}{l}\text { feedback from Prof. } \\
\text { Terry Williams }\end{array}$ & $3^{\text {rd }}$ draft of this paper \\
\hline Q2-2019 & $\begin{array}{l}\text { arguing for conceptual } \\
\text { impacts }\end{array}$ & $\begin{array}{l}\text { evidencing conceptual } \\
\text { impact case studies } \\
\text { (ICS) }\end{array}$ & $\begin{array}{l}\text { peer review from } \\
\text { social network of } \\
\text { author A }\end{array}$ \\
\hline Q3-2019 & $\begin{array}{l}\text { participating in REF } \\
\text { planning meetings }\end{array}$ & $\begin{array}{l}\text { research seminar } \\
\text { (Brauer, Barnes, \& } \\
\text { Hollinshead 2019) }\end{array}$ & $\begin{array}{l}\text { amending of ethical } \\
\text { problems with data set }\end{array}$ \\
\hline Q4-2019 & $\begin{array}{l}\text { correspondence with } \\
\text { Dr Dionysios Demits }\end{array}$ & $\begin{array}{l}\text { feedback from Prof. } \\
\text { Simon Green }\end{array}$ & $\begin{array}{l}\text { internal peer review } \\
\text { amongst co-authors }\end{array}$ \\
\hline Q1-2020 & $\begin{array}{l}\text { proofreading by native } \\
\text { English speaker }\end{array}$ & $\begin{array}{l}\text { research seminar } \\
\text { (Brauer, 2020) }\end{array}$ & $\begin{array}{l}\text { inclusion of this table } \\
\text { into the paper }\end{array}$ \\
\hline Q2-2020 & $\begin{array}{l}\text { feedback on research } \\
\text { programme (RP) }\end{array}$ & $\begin{array}{l}\text { addressing comments } \\
\text { on RP via review sheet }\end{array}$ & $\begin{array}{l}\text { articulation of life-long } \\
\mathrm{RP}\end{array}$ \\
\hline Q3-2020 & $\begin{array}{l}\text { peer review feedback } \\
\text { from } 1^{\text {st }} \text { submission }\end{array}$ & $\begin{array}{l}\text { two desk rejections } \\
\& \text { one rejection for } \\
\text { publication }\end{array}$ & $\begin{array}{l}4^{\text {th }} \text { draft of this paper } \\
\text { as a conceptual one }\end{array}$ \\
\hline Q4-2020 & $\begin{array}{l}\text { discussion of reasons } \\
\text { of rejection with peers }\end{array}$ & $\begin{array}{l}\text { RP published (Brauer, } \\
\text { Dymitrow, \& Tribe, } \\
\text { 2021) }\end{array}$ & $\begin{array}{l}\text { re-writing several } \\
\text { conceptual ICS }\end{array}$ \\
\hline Q1-2021 & $\begin{array}{l}\text { seminar with } \\
\text { nollatutkijat (University } \\
\text { of Eastern Finland, } \\
\text { 2021) }\end{array}$ & $\begin{array}{l}\text { systematic review of } \\
\text { "zero impact" research } \\
\text { group feedback } \\
\text { (Finish translation) }\end{array}$ & $\begin{array}{l}\text { trial narrative at staff } \\
\text { training for Faculty } \\
\text { of Business Law and } \\
\text { Politics (Brauer, 2021) }\end{array}$ \\
\hline Q2-2021 & $\begin{array}{l}\text { resubmission as new } \\
\text { conceptual article }\end{array}$ & $\begin{array}{l}\text { one desk rejection } \\
\text { and two rejections for } \\
\text { publication }\end{array}$ & $\begin{array}{l}\text { REF } 2021 \text { submission } \\
\text { finalisation }\end{array}$ \\
\hline Q3-2021 & $\begin{array}{l}\text { informal addressing } \\
\text { reasons for rejections }\end{array}$ & submission to JECS & $\begin{array}{l}\text { inclusion of figure } 3 \text { to } \\
\text { highlight bifurcation } \\
\text { of scientific logic }\end{array}$ \\
\hline
\end{tabular}

Source: own research

Any form of disciplining needs material reinforcement to accomplish anything, regardless of whether it is geared towards the advancement of knowledge or impact. A valuation regime geared towards impact can construe the above-described activities as wasteful as impact has not yet occurred. A valuation regime geared towards the advancement of knowledge can perceive them as a rigours account of how to challenge the normalised assumption around the research impact regime. Yet, it is the same behaviour and claims to new knowledge which are being judged. We could draw a similar table for each of the authors, but we omitted it for the sake of brevity. Please note that 
some of the examples stretch over the quarters, as so much complexity is not easily commodified/articulated. We argue from an individual perspective how such conduct is valued is impossible to determine when it comes to new knowledge, we obviously deem it highly important as otherwise we would not have invested the time and effort. Yet, it is still possible to dismiss our criticism of the impact agenda as a delusion. Indeed, this may be the case, but at least it is $\mathrm{a}((\mathrm{n} 1+\mathrm{n} 2 \ldots+\mathrm{nX})=\mathrm{n}(\mathrm{A})+\mathrm{n}(\mathrm{B})+\mathrm{n}(\mathrm{C})+\mathrm{n}(\mathrm{D})=$ type of delusion. A, B, C \& D represents the social networks of the respective authors, and $n$ all the different time we searched again to verify our argument, i.e. our research.

Genuine new knowledge always teeters on the edge between profoundness or delusion, and the above-described instances helped us identify the categories and concepts we are using here to articulate and convey our argument. Accumulatively, each rejection/instance of communication breakdown represented instances where we refined the articulation of our argument. By conceptualising each of these rejections as a learning experience towards the advancement (of our own) knowledge, such ruptures of communications transform into data instead of fuelling aggravation, aggression and ultimately violence. That in its totality now represents the grounds for the here present articulation. What aided us in our rhetorical re-construction was the ideal of scientific truth and the associated disciplinary procedures learned from individuals that best reaffirmed this ideal according to the opinion of the authors (some of who we asked for advise, see Table 1), who learned it from their elders, who in turn learned it from their elders, passing down that spirit of inquiry of not accepting the status quo throughout the generations (Gadamer, 1960/2004). As Friedrich Nietzsche writes, in the Future of our Educational institutions: "that earnest, manly, stern, and daring German spirit; that spirit of the miner's son, Luther, which has come down to us unbroken from the time of the Reformation" (Nietzsche, 1872/2009, p. 139). Given the historicity of this role model/spirit we are here emulating, it should be self-evident why it cannot help itself of coming into conflict with undeserved claims of authority by merely asking questions.

Today we are at the end of this long evolution and trial and error process of finding a shared scientific logos that does work in human communication for contentious issues which transformed the Christian (holy) spirit into scientific reason (Hannam, 2011). In our estimation, the sin of the impact agenda is that it disrupts this process of mutual learning as the individual then has allowed the end to justify the means, completely squashing the golden goose of innovation, inspiration, and progress without even realising it. The perceived need to act before it gets too late prevents the growth and transmission of scientific knowledge, values, and skills within the research ecosystem from the bottom up. The resulting moral economy is then no longer structured by who can best performatively enact these values and enculture the next generation. The associated interaction ritual chains that maintained the fecundity of the created emotional energy that sustained social cohesion (Collins R., 2005) and the integrity of the created argument is not only damaged, but potentially 
this disruption is irreparable. Only the proper framing is what systematically distinguishes esoteric scribbles (see Fig. 2) and delusions from scientific data material. Such scientific conduct creates the objective facts (Hoyningen-Huene, 2013), with the goal being the advancement of knowledge. At least that is what we found in our own research methodology.
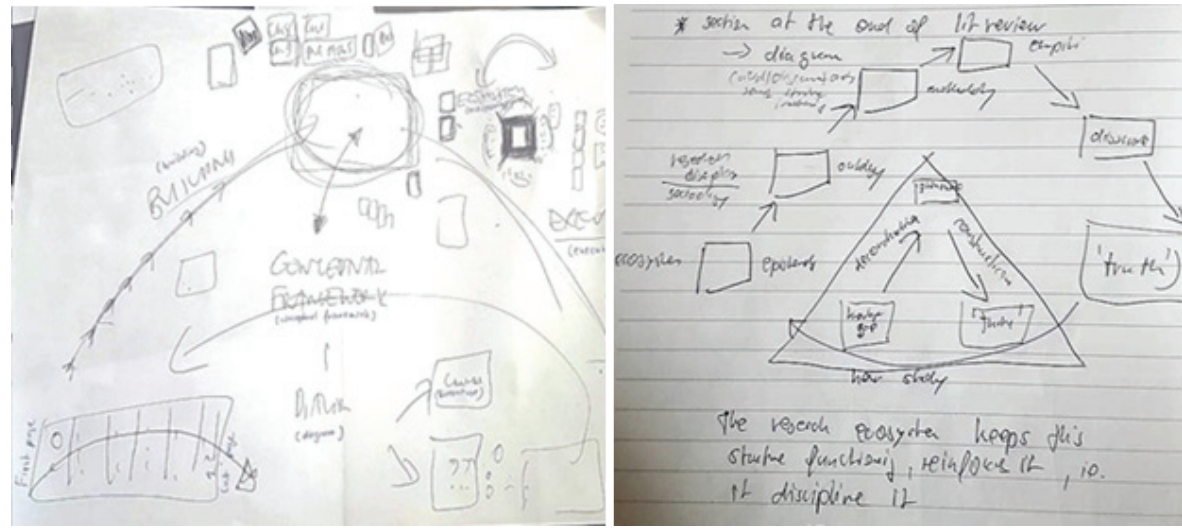

Fig. 2. The left image represents Professor Tribe's sketch of the research process that served as inspiration for Figure 1, the right picture represents Brauer's first sketch (who did not hold the doctoral degree at the time).

Source: own research

\section{Consequences for advancing knowledge on a general level}

If we modestly speculate about the general consequences of the impact agenda, we argue that we not only have to find workable ways of how to include it but also a new language with which we can address its emergent problems. If we do not, there will be no difference between research and activism. The contribution of our paper is thus to label all adverse aspects of the impact agenda as the impact or starve paradigm, taking inspiration from the publish or perish naming convention that allowed for the identification of similar unintended consequences (Moosa, 2018). Every cure starts with a diagnosis. It is easy to take the moral high ground and deem the introduced evaluation structure as detrimental, in that it prioritises outcome and not the process. As we have outlined here, the problem with impact is axiological and not just procedural; whose values, whose authority of valuation gets priority and what are the reasons for it? In order to recognise any form of impact, one needs a frame of reference and this inadvertently situates itself in contemporary (imperfect) assumptions of a specific cultural/political/ideological background. Henceforth, the very act of critical, but constructive, communication also represents an avenue for a solution. The advancement of knowledge not only continues our Western value structure, but also prevents contemporary values from becoming despotic. Karl Popper (1962, p. 501) writes: "[i]t is one of the most important inventions ever made. Indeed, the possibility of fighting with words 
instead of fighting with swords is the very basis of our civilisation, and especially of all its legal and parliamentary institutions."

Scientific truths and the research ecosystem that produces them are the results of the application of disciplinary regimes, creating the resulting dialectic that enables this very articulation. The sociological model of the scientific method presented here is, in essence, the sociological articulation of Hegelian dialectic (thesis > antithesis > synthesis) "through which spirit becomes pure knowledge" (Hegel, 1807/1979, p. 468). We stress that the integrity of scientific facts inextricably links to a value commitment of the advancement of knowledge of its practitioners, i.e., researchers. Here we intended to show how this process unfolds within a pertinent example, namely this paper, which, when published and quoted, will become a scientific fact. If we are wrong, please tell us in print, aiding the collective articulation and advancement of knowledge around the detriments of the impact agenda. Now, the way that this paper achieves its scientific validity is not only by theoretically describing how the scientific method functions, adhering to methodological and ethical guidelines, structuring our arguments in a logical manner, and stating our contribution. More than this, every idea, every sentence, every word has been socially constructed to "walk the talk" (Collins H. M. \& Evans, 2008, p. 91).

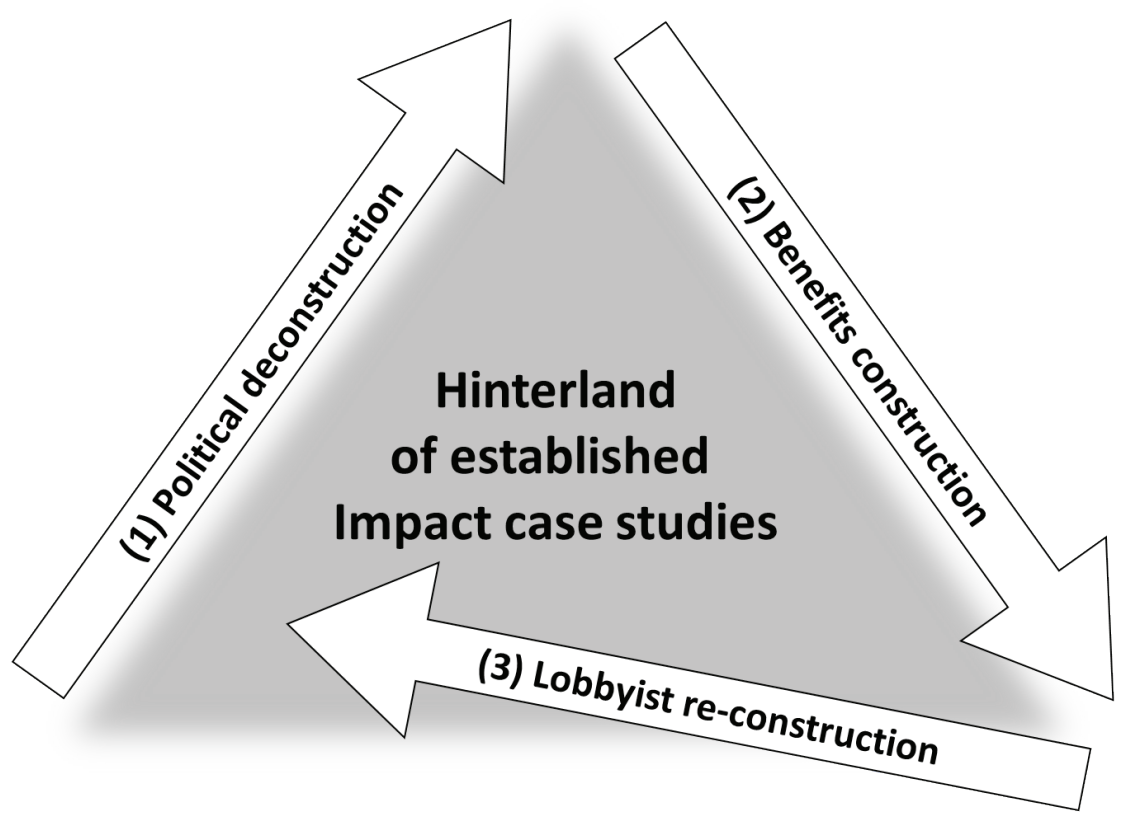

Fig. 3. The sociological dynamics of the impact or starve paradigm visualised Source: own research 
Albeit the framing of impact or starve is arguably categorical, this very article is also role modelling how the skilful mastery of the scientific method allows for questioning deeply ingrained conventions without communication rupturing. The impact or starve paradigm functions differently epistemologically, due to its different value commitment dissent is detrimental and not invigorating. Figure 3 illustrates how this new paradigm masquerades as scientific authority, following a similar logic as scientific reason (see Fig. 1). Yet, instead of a critical deconstruction of the existing state of knowledge to situate a knowledge gap, it is enough to affiliate one's research agenda with a political aim that ascertains benefit. Within the political deconstruction (1), the steps to achieve the selected goal are then deconstructed and not the goal. Criticism on this level would cast doubt on the very framing of the described activities furthering the goal. The analytical construction in a research context carefully looked for counterevidence as well as affirmative results. In the analogous benefits construction (2) only data that reaffirms the argument of the impact claim is mentioned, in order to make the claim as grandiose as possible, i.e., significant. Henceforth, the rhetorical re-construction that used to aim for a neutral recounting of the observed results changes into a lobbyist re-construction (3) where the narrative reigns supreme in order to be favourably judged in a status hierarchy. Individuals conditioned within this mode of thinking cannot even comprehend that communication is part of the explorative process; instead, they merely try to convince the reader of their own agenda.

The resulting tensions are not easily resolved, because whilst idealistic notions of truth and academic freedom are undoubtedly foundational to academic integrity, an equal imperative is that any process needs resources to sustain itself, the research process being no different. It is this pragmatism, to which the starve metaphor is referring towards the withdrawal of resources needed to question such conventions. If such initial 'useless' conduct is punished for not conforming to an impact regime, and not allowed to grow and develop through nurturing over time - acquiring more and more sophistication along the way - but rather is met with the cold scorn of a disciplinary requirement, only politically correct 'innovation' is then tolerated. Hence, the only way to pre-empt such an ossification of contemporary values is through the medium of communicating which specific aspects we find detrimental and why. This article is our effort to do so, using our own argument construction to point out the resulting tensions. Arguably, an explicit focus on advancing knowledge is what legitimises our assertions as objective.

\section{CONCLUSION}

To conclude and answer our titular research question, our answer is that the scientific truth ideal enables non-violent conflict resolution for Western society in general. In that, this metaphor cements the value of scientific truth and the advancement of knowledge, allowing researchers to question the supposed 
utility of any phenomenon. Such a process constantly updates societies' Zeitgeist according to newly emergent information. A shift to evaluating research based on its impact is possible, but inadvertently undermines the advancement of knowledge, instead reshaping and re-construing research as a conflict of political power. In addition to our contribution to knowledge of outlining how the epistemological regime of impact claims functions, we can identify two further unintended consequences. Firstly, individuals who were unquestionably rule-compliant with the impact or starve paradigm will be dumbfounded by any unintended consequences, as they themselves allowed the ends to justify the means, which refusal to do so previously enabled non-violent conflict resolution. Secondly, young critics will be ostracised as useless and disruptive, foregoing their re-invigorating potential of being the innovators of tomorrow. This is because the time and effort necessary to nurture their creativity and articulation of their ideas will be deemed wasteful, i.e. non-impactful. The limitations of this research are the very limits of our perception and our associated research ecosystem. We acknowledge that what is personal may also be political. However, if these politically personal agendas are institutionally rewarded, is it still research we are dealing with, or is it activism?

\section{ACKNOWLEDGMENTS}

The authors want to thank everyone that made this sociology of science possible. The individuals mentioned within Table 1 agreed to be mentioned within this capacity. The argument presented here is our own, and any potential mistakes and/or omissions of our polemic are equally our own. No funding was received for this research.

\section{REFERENCES}

[1] Allbutt, H., \& Irvine, S. (2021). Research assessment in a National Health Service organisation: a process for learning and accountability. Evidence \& Policy: A Journal of Research, Debate and Practice, 1-13.

[2] Angell, I. O., \& Demetis, D. (2010). Science's first mistake: Delusions in pursuit of theory. A\&C Black.

[3] Barnett, R. (1990). The idea of higher education. McGraw-Hill Education (UK).

[4] Biagioli, M., Kenney, M., Martin, B., \& Walsh, J. P. (2018). Academic misconduct, misrepresentation and gaming: A reassessment. Research Policy, 48(2), 401-413.

[5] Bonaccorsi, A., Melluso, N., Chiarello, F., \& Fantoni, G. (2021). The credibility of research impact statements: A new analysis of REF with Semantic Hypergraphs. Science and Public Policy, 48(2), 212-225.

[6] Bourdieu, P. (1988). Homo academicus. Stanford University Press. (Original work published 1984)

[7] Brauer, R. (2018). What research impact? Tourism and the changing UK research ecosystem [Doctoral dissertation, University of Surrey].

[8] Brauer, R. (2019). Understanding collective knowledge production: What lessons can be learned from controversy? In M. Dymitrow \& K. Ingelhag (Eds.). Anatomy of a 21st-century sustainability project (pp. 78-90). Mistra Urban Futures. 
[9] Brauer, R. (2020). Research impact, ethics and academic integrity, Institute of Applied Ethics, Hull, UK 10th of March 2020.

[10] Brauer, R. (2021). Impact and the (new) research ecosystem. Workshop on research impact for the Faculty of Business Law and Politics, University of Hull, 26th of May 2021.

[11] Brauer, R., Arsovski, S. \& Dymitrow, M. (2021). Universities, the categorical imperative and responsible research. STS Conference Graz 2021, 3rd of May 2021.

[12] Brauer, R., Barnes, R., \& Hollinshead, K. (2019). What is the purpose of a university in the 21st century?, Bacchus Institute of Science, Hull, UK, 12th of June 2019.

[13] Brauer, R., \& Dymitrow, M. (2017). Human geography and the hinterland: The case of Torsten Hägerstrand's 'belated' recognition. Moravian Geographical Reports, 25(2), 74-84.

[14] Brauer, R., Dymitrow, M., \& Tribe, J. (2019). The impact of tourism research. Annals of Tourism Research, 77, 64-78.

[15] Brauer, R., Dymitrow, M., Worsdell, F., \& Walsh, J. (2020). Maculate reflexivity: Are universities losing the plot?. 7th International Conference Education Culture Society, 12th of September 2020

[16] Brauer, R., \& Dymitrow, M. (2021). The language of sustainable tourism as a proxy indicator of research quality. Sustainability, 13(1), 25.

[17] Brauer, R., Dymitrow, M., \& Tribe, J. (2021). A wider research culture in peril: A reply to Thomas. Annals of Tourism Research, 86(1).

[18] Campbell, D. T. (1974). Evolutionary epistemology. In P. A. Schlipp (Ed.). The philosophy of Karl Popper (pp. 413-463). Open Court Publishing Company.

[19] Chubb, J., \& Reed, M. S. (2018). The politics of research impact: Academic perceptions of the implications for research funding, motivation and quality. British Politics, 13(3), 295-311.

[20] Collins, H. M. (2010). Gravity's shadow. University of Chicago Press.

[21] Collins, H. M., \& Evans, R. (2008). Rethinking expertise. University of Chicago Press.

[22] Collins, H. M., \& Pinch, T. J. (1979). The construction of the paranormal: Nothing unscientific is happening. The Sociological Review, 27(1), 237-270.

[23] Collins, R., (2005). Interaction ritual chains. Princeton University Press.

[24] Crawford, A. (2020). Societal impact as 'rituals of verification' and the co-production of knowledge. The British Journal of Criminology, 60(3), 493-518.

[25] Finch, D. J. (2016) Lessons from REF 2014. Research Excellence and the Social Science. Academy of Social Sciences Professional Briefings, 6, 2-6.

[26] Deleuze, G., \& Guattari, F. (1988). A thousand plateaus: Capitalism and schizophrenia. Bloomsbury Publishing.

[27] Dymitrow, M., \& Brauer, R. (2017). Performing rurality. But who? Bulletin of Geography. Socioeconomic Series, 38, 27-45.

[28] Dymitrow, M., \& Brauer, R. (2018). Meaningful yet useless? Factors behind the retention of questionable concepts in human geography. Geografiska Annaler: Series B, Human Geography, 100(3), 195-219.

[29] Dymitrow, M., \& Ingelhag, K. (2020). Anatomy of a 21st-century sustainability project: The untold stories. Urban Mistra Futures.

[30] Edwards, P. N. (2010). A vast machine: Computer models, climate data, and the politics of global warming. MIT Press.

[31] ESRC (2021, August 10). Doctoral training. Retrieved from https://esrc.ukri.org/ skills-and-careers/doctoral-training/

[32] ESRC (2020, August 12). What is impact?. Retrieved from http://www.esrc.ac.uk/research/ evaluation-and-impact/what-is-impact/.

[33] Etzkowitz, H., \& Leydesdorff, L. A. (1997). Universities and the global knowledge economy. Pinter.

[34] Feyerabend, P. (1993). Against method. Verso.

[35] Fleck, L. (1986). The problem of epistemology. Cognition and fact. Boston Studies in the Philosophy of Science, 87, 79-112. (Original work published 1936)

[36] Flink, T., \& Peter, T. (2018). Excellence and frontier research as travelling concepts in science policymaking. Minerva, 56(4), 431-452.

[37] Foucault, M. (2001). The order of things. Routledge. (Original work published 1966)

[38] Foucault, M. (1972). Archaeology of knowledge. Pantheon.

[39] Gadamer, H. G. (2004). Truth and method (2 ${ }^{\text {nd }}$ ed.). Continuum. (Original work published 1960)

[40] Gardner, J. W. (1968). No easy victories. The American Statistician, 22(1), 14-16. 
[41] Gieryn, T. F. (1999). Cultural boundaries of science: Credibility on the line. University of Chicago Press.

[42] Götz, N. (2015). 'Moral economy': Its conceptual history and analytical prospects. Journal of Global Ethics, 11(2), 147-162.

[43] Habermas, J. (1968). Technik und Wissenschaft als 'Ideologie'. Suhrkamp.

[44] Hannam, J. (2009). God's philosophers: How the Medieval world laid the foundations of modern science. Icon Books Ltd.

[45] Hannam, J. (2011). The genesis of science: How the Christian Middle Ages launched the scientific revolution. Regnery Publishing.

[46] HEFCE (2007, March 6). Research excellence framework, 2007/34. Retrieved from https:// webarchive.nationalarchives.gov.uk/20100303171159/http:/www.hefce.ac.uk/pubs/ circlets/2007/cl06_07/

[47] HEFCE (2011, March 1). Decisions on assessing impact. Retrieved from https://www.ref. ac.uk/2014/pubs/2011-01/

[48] HEFCE (2015, January 23). REF 2014 - Key facts. Retrieved from https:/ / www.ref.ac.uk/2014/ pubs/keyfacts/

[49] HEFCE (2019, January 1). Guidance on submissions. Retrieved from https://www.ref.ac.uk/ publications/guidance-on-submissions-201901/

[50] Hegel, G. W. F. (1979). The phenomenology of spirit. Oxford University Press. (Original work published 1807)

[51] Hicks, D. (2012). Performance-based university research funding systems. Research Policy, 41(2), 251-261.

[52] Hicks, D., \& Holbrook, J. B. (2020). A cartography of philosophy's engagement with society. Minerva, 58(1), 25-45.

[53] HM Treasury (2006, December 6). Investing in Britain's potential, pre-budget report, Cm 6984. HMSO. Retrieved from https://www.gov.uk/government/publications/investing-inbritains-potential-building-our-long-term-future-pre-budget-report-december-2006

[54] Holbrook, J. B. (2017). The future of the impact agenda depends on the revaluation of academic freedom. Nature: Palgrave Communications, 3(39), 1-9.

[55] Hoyningen-Huene, P. (2013). Systematicity: The nature of science. Oxford University Press.

[56] Ingold, T. (2020). On building a university for the common good. Philosophy and Theory in Higher Education, 2(1), 45-68.

[57] Irwin, R. (2007). The neoliberal state, environmental pragmatism, and its discontents. Environmental Politics, 16(4), 643-658.

[58] Jones, N. L., Cooke, J., \& Holliday, J. (2021). Making occupational therapy research visible: amplifying and elevating the contribution and impacts. British Journal of Occupational Therapy.

[59] Kaufmann, M. T. (2003, February 24 ). Robert K. Merton: Versatile sociologist and father of the Focus Group, dies at 92. The New York Times. Retrieved from https:/ / www.nytimes. com/2003/02/24/nyregion/robert-k-merton-versatile-sociologist-and-father-of-the-focusgroup-dies-at-92.html.

[60] Kidd, I. J., Chubb, J., \& Forstenzer, J. (2021). Epistemic corruption and the research impact agenda. Theory and Research in Education, 19(2), 148-167.

[61] Kohler, R. E. (1994). Lords of the fly: Drosophila genetics and the experimental life. University of Chicago Press.

[62] Lakoff, G., \& Johnson, M. (2008). Metaphors we live by. University of Chicago Press.

[63] Lambert, H. (2019, August 21). The great university con: How the British degree lost its value. New Statesman. Retrieved from https://www.newstatesman.com/politics/ education/2019/08/great-university-con-how-british-degree-lost-its-value

[64] Lamont, M. (2009). How professors think. Harvard University Press.

[65] Latour, B. (1988). Science in action: How to follow engineers and scientists through society. Harvard University Press.

[66] Latour, B. (2005). Reassembling the social: An introduction to actor-network-theory. Oxford University Press.

[67] Latour, B. (2013). An inquiry into modes of existence: An anthropology of the moderns. Harvard University Press.

[68] Lauronen, J. P. (2020). The dilemmas and uncertainties in assessing the societal impact of 
research. Science and Public Policy, 47(2), 207-218.

[69] Law, J., \& Urry, J. (2004). Enacting the social. Economy and Society, 33(3), 390-410.

[70] Law, J. (2004). After method: Mess in social science research. Routledge.

[71] Livingstone-Banks, M. (2020, July 3). No more Pathways to Impact: how impact is being embedded into research grant proposals. University of Oxford. Retrieved from https://www. mpls.ox.ac.uk/public-engagement/latest/no-more-pathways-to-impact-how-impact-isbeing-embedded-into-research-grant-proposals.

[72] Luhmann, N. (1992). What is communication?. Communication Theory, 2(3), 251-259.

[73] Luhmann, N. (2002). Das Erziehungssystem der Gesellschaft. Suhrkamp. (Original work published 1978)

[74] Macfarlane, B. (2019). The neoliberal academic: Illustrating shifting academic norms in an age of hyper-performativity. Educational Philosophy and Theory, 1-10.

[75] MacKenzie, D. (2009). Material markets: How economic agents are constructed. Oxford University Press.

[76] Martin, B. R. (2011). The Research Excellence Framework and the 'impact agenda': Are we creating a Frankenstein monster?. Research evaluation, 20(3), 247-254.

[77] McCabe, A., Osegowitsch, T., Parker, R., \& Cox, S. (2021). Knowledge co-production in academic-practitioner research collaboration: An expanded perspective on power. Management Learning.

[78] Merton, R. K. (1973). The sociology of science: Theoretical and empirical investigations. University of Chicago Press.

[79] Messner, C., \& Brügger, A. (2015). Nazis by Kraut: A playful application of moral self-licensing. Psychology, 6, 1144-1149.

[80] Mol, A. (2002). The body multiple: Ontology in medical practice. Duke University Press.

[81] Moosa, I. A. (2018). Publish or perish: Perceived benefits versus unintended consequences. Edward Elgar Publishing.

[82] Nietzsche, F. (2009). On the future of our educational institutions. The Project Gutenberg EBook. (Original work published 1872)

[83] Pinker, S., \& Prince, A. (2002). The nature of human concepts: Evidence from an unusual source. In P. Van Loocke (Ed.) The nature of concepts: Evolution, structure and representation. (pp. 8-51). Routledge.

[84] Pinker, S. (2015). The sense of style: The thinking person's guide to writing in the 21st century. Penguin Books.

[85] Pinker, S. (2018). Enlightenment now: The case for reason, science, humanism, and progress. Penguin Books.

[86] Polanyi, M. (2000). The republic of science: Its political and economic theory. Minerva, 38(1), 1-32. (Original work published 1962)

[87] Popper, K. R. (1962). Conjectures and refutations: The growth of scientific knowledge. Basic Books.

[88] Porter, R. (1977). The making of geology: Earth science in Britain 1660-1815. Cambridge University Press.

[89] Reed, M. S. (2018). The research impact handbook (2nd ed.). Fast Track Impact Ltd.

[90] Sayer, D. (2014). Rank hypocrisies: The insult of the REF. Sage.

[91] Shapin, S. (2010). Never pure: Historical studies of science as if it was produced by people with bodies, situated in time, space, culture, and society, and struggling for credibility and authority. John Hopkins University Press.

[92] Shields, R., \& Watermeyer, R. (2020). Competing institutional logics in universities in the United Kingdom: schism in the church of reason. Studies in Higher Education, 45(1), 3-17.

[93] Smith, S., Ward, V., \& House, A. (2011). 'Impact'in the proposals for the UK's Research Excellence Framework: Shifting the boundaries of academic autonomy. Research Policy, 40(10), 1369-1379.

[94] Stahl, B. C., Chatfield, K., Ten Holter, C., \& Brem, A. (2019). Ethics in corporate research and development: can responsible research and innovation approaches aid sustainability?. Journal of Cleaner Production, 239, 118044.

[95] Star, S., \& Griesemer, J. (1989). Institutional ecology, 'translations' and boundary objects: Amateurs and professionals in Berkeley's Museum of Vertebrate Zoology, 1907-39. Social Studies of Science, 19(3), 387-420.

[96] Strathern, M. (2000). The tyranny of transparency. British Educational Research Journal, 26(3), 
309-321.

[97] Sztompka, P. (2007). Trust in science: Robert K. Merton's inspirations. Journal of Classical Sociology, 7(2), 211-220.

[98] Ten Holter, C. (2020). The repository, the researcher, and the REF: "It's just compliance, compliance, compliance". The Journal of Academic Librarianship, 46(1), 102079.

[99] Tribe, J., \& Liburd, J. J. (2016). The tourism knowledge system. Annals of tourism research, 57, 44-61.

[100]Tribe, J. (2010). Tribes, territories and networks in the tourism academy. Annals of tourism research, 37(1), 7-33.

[101]University of Oxford, (2021, August 10). Research impact. Retrieved from http://www.ox.ac. $\mathrm{uk} /$ research/research-impact.

[102]Warry, P. (2006). Increasing the economic impact of research councils. Department for Business.

[103]Watermeyer, R. (2019). Competitive accountability in academic life: The struggle for social impact and public legitimacy. Edward Elgar Publishing.

[104]Watermeyer, R., \& Chubb, J. (2019). Evaluating 'impact'in the UK's Research Excellence Framework (REF): liminality, looseness and new modalities of scholarly distinction. Studies in Higher Education, 44(9), 1554-1566.

[105]Weingart, P. (1999). Scientific expertise and political accountability: paradoxes of science in politics. Science and Public Policy, 26(3), 151-161.

[106]Williams, K., \& Grant, J. (2018). A comparative review of how the policy and procedures to assess research impact evolved in Australia and the UK. Research Evaluation, 27(2), 93-105.

[107]Wittgenstein, L. (1986). Philosophical investigations (3rd ed.). Basil Blackwell Ltd. (Original work published 1953)

[108]Woit, P. (2006). Not even wrong: The failure of string theory and the search for unity in physical law. Basic Books.

[109]Woolcott, G., Keast, R., \& Pickernell, D. (2020). Deep impact: re-conceptualising university research impact using human cultural accumulation theory. Studies in Higher Education, 45(6), 1197-1216.

[110]Wouters, P., Thelwall, M., Kousha, K., Waltman, L., de Rijcke, S., Rushforth, A., \& Franssen, T. (2015). The metric tide. Literature review. Supplementary report I to the independent review of the role of metrics in research assessment and management. HEFCE.

[111]Wróblewska, N. (2021). Research impact evaluation and academic discourse. Nature: Humanities and Social Sciences Communications, 8(1), 1-12. 